\title{
DEVELOPING STUDENTS' VOCABULARY MASTERY THROUGH VIDEO GAME
}

\author{
DIAN SAPUTRA \\ Department of English Education, Faculty of Teacher Training and Education, \\ University of Muhammadiyah Sorong
}

Email: dian.ums14@gmail.com

\begin{abstract}
The objective of this study was trying to analyze the impact of using video game in developing student's vocabulary mastery. The method of this study was quantitative. The design of the research was based on the experimental study. Pre-test and post-test was given to 37 students of class H fifth semester of Sorong Muhammadiyah University. Score of the test was divided into five categories, they were very good, good, fairly, poor and very poor. The mean score of pre-test was 6, 51 in fairly category and the mean score of post-test was 8,5 in very good category. It showed that the mean score of test after given the treatment was higher than test before given the treatment. The result of the t-test showed that played video games gave a significant effect on the students' vocabulary mastery. The result of t-test was higher than $t$ table $(8,96>1.68830)$.
\end{abstract}

Keywords: video games, vocabulary mastery

\section{Introduction}

The phenomenon of games now is booming in this world from the developed countries until developing countries except Indonesia, from a big city until a rural area had been known video games. But peoples didn't understand when they played video games would been making brain or knowledge developed. Moreover, that have much attention has been directed to the use video games for learning in recent years. There were several study mention about this area such as Gee (2005), Johnson, et al (2005), Gros (2007). This review of the literature on video game research focuses on publications analyzing educational game design, namely those that present design elements conducive to learning, the theoretical underpinnings of game design, and learning outcomes from video game play, Prensky (2006). In part due to the staggering amounts of capital spent on games in the entertainment industry, but also because of their ability to captivate player attention and hold it for lengthy periods of time as players learn to master game complexities and accomplish objectives. 
The good video games can helped the player to learn and developed creativity. Moreover, in educational context, video games produce sentences that contains words, phrase, and meaning. It can be one of the media to learning language, and the component of language is vocabulary. Vocabulary is one important aspect in learning a foreign language. With a limited vocabulary anyone will also has a limited understanding in terms of speaking, reading, listening, and writing. It is true that it might be impossible to learn a language without mastering vocabulary.

Vocabulary is one of the problems confronted by English language learners. Because of the limited vocabulary, the learners cannot communicate to others clearly. Sometimes it is difficult to group students make school work easier and more rewarding, and also many tests that they take in school include vocabulary questions. More vocabularies they know the better their chance to do well on an English test. The acquisition of a large number of vocabularies can help the students communicate with other peoples. A good vocabulary and ability to use words correctly and effectively can help the students in developing vocabulary. Based on the above description the researcher feels interest to study the role of video games to develop students' vocabulary building under the topic of developing Students' vocabulary mastery through video game.

\section{Problem Statement}

The researcher formulate the problem statement: Can the use of video game able to develop students' vocabulary mastery?

\section{Significance of the Research}

This research will give benefit to those people who is get involved surround the educational issue, especially to the teacher of language which is facing many difficulties during the lesson. If the result appeared and proved that there is a significance influence of video games to the students' vocabulary during the experimental that researcher have conducted, the school or any related institution will make a new policy to spread the use of video games in order to develop their students' vocabulary. 
Hypothesis

Based on the relevant theories or explanation forward. So the researcher can hypothesize;

$\mathrm{H}_{\mathrm{o}}$ (Null Hypothesis) playing video game cannot develop the students' vocabulary mastery at class $\mathrm{H}$ fifth semester of Sorong Muhammadiyah University.

$\mathrm{H}_{\mathrm{a}}$ (Alternative Hypothesis) playing video game can develop the students' vocabulary mastery at class $\mathrm{H}$ fifth semester of Sorong Muhammadiyah University.

\section{RESEARCH METHOD AND DESIGN}

The method used in this research was a quantitative method which disclosed the use of video game to develop students' vocabulary mastery. This relies on quantitative data based on computation and measurement and statistic. In this research, the researcher used quantitative research through pre-experiment. In this case, the researcher used a design that called the one group pretest posttest procedure (Syamsuddin, 2006)

\section{Population and Sample}

The population of this study was the students of English Department of Training and Education Faculty of Sorong Muhammadiyah University academic year 2012-2013 that consist of 423 students. The sample which is taken all students in class H fifth semester of Sorong Muhammadiyah University consist of 37 students.

\section{Research Procedure}

The procedures of this research was to minimizing the threats to experimental validity. Pretests are administered before the application of the treatments and post tests at the end of the treatment period. Gain scores may be compared and subjected to a test of significance of the difference between two means.

\section{Research Instrument}

In order to investigate the students' vocabulary mastery, a test was used. This test consisted of 40 items. The same test version was administered twice as pretest and posttest. 


\section{Data Analysis}

To evaluate the students' vocabulary mastery, the writer would try to find out the score of every students'. The procedure would undertake in the data analyzed as follows:

a. Scoring the students' ability by using the formula as formula:

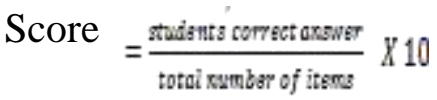

b. To determine high or low the score of the students, the writer employ the rating score as follows;

$\begin{array}{ll}\text { Category } & \text { score } \\ \text { Very good } & 8.0-10 \\ \text { Good } & 6.6-7.9 \\ \text { Fairly } & 5.6-6.5 \\ \text { Poor } & 4.0-5.5 \\ \text { Very poor } & 0.0-3.9\end{array}$

(Arikunto, 1984)

c. Finding out the mean score of the students' answer by using the following formula:

$$
\overline{\mathrm{X}}=\frac{\sum \mathrm{x}}{\mathrm{N}}
$$

Whereas:

$\bar{X}=$ Mean score

$\sum^{x}=$ The number of total score

$n=$ The number of students

(Arikunto, 1996)

d. To find the distribution between score of pre-test and post-test the researcher computed the sum of squared deviation based on the formula by as follows:

$$
\sum \mathrm{X}^{2} \mathrm{~d}=\sum \mathrm{d}^{2}-\frac{\left(\sum \mathrm{d}^{2}\right)}{\mathrm{N}}
$$

Where:

$\sum \mathrm{X}^{2} \mathrm{~d}=$ the sum of square deviation

$\sum \mathrm{d}^{2}=$ the sum of deviation

$\mathrm{N} \quad=$ Number of students

(Arikunto, 1996)

e. The last is to prove the significance different between the mean score achievement, the researcher use the formula by as follows:

$$
t=\frac{M d}{\sqrt{\sum X^{2} d}}
$$




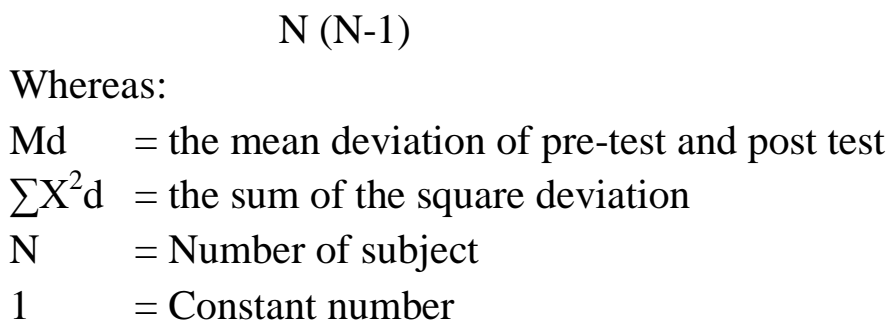

\section{FINDINGS AND DISCUSSION}

This chapter presented the data gathered from each activity. These activities covered data acquired from the evaluations. The evaluations consisted of pre-test and post-test. The aim of the activities were to know whether the students would have a good changing in their playing of video games or even became worse after getting the treatments.

The test consisted of 40 items. The aim of the test was to measure whether or not the students were familiar with the words in video games. It involved the whole students in the class $\mathrm{H}$ that consisted of 37 students.

1. Data of Obtained Score from Pre-test

The result of the students' pretest shows that the mean score of the students on pretest was $6.51(241: 37=6.51)$

2. Data of Obtained Score from Post-test

Data above shown us the result of the students' post test. The mean score of the students on pre-test was $8.5(314.5: 37=8.5)$

3. Data of Distribution of Pre-Test and Post-Test Score

The researcher computed the sum at square deviation based on the formula: Data shown the distribution of pre-test and post-test, the sum at square deviation was 66.25

After computed the square deviation, the researcher calculating to prove the significance difference between the mean score achievement. The computation can be seen below: $t_{\text {table }}$ for DF (Degrees of Freedom) 36 was $1.68830 t_{\text {test }}$ was compared with $t_{\text {table }}$ with the error level was 0.05 , and $d k=37(\mathrm{~N}-1)$. The result showed that $t$ test was higher than $\mathrm{t}_{\text {table }} ; \mathrm{t}_{\text {test }}$ was 8,96 while $\mathrm{t}_{\text {table }}$ was $1.68830(8.96>1.68830)$. It means that there was a significant effect of playing video game to develop vocabulary mastery at class $\mathrm{H}$ fifth semester of Sorong Muhammadiyah University. 


\section{Discussion}

After analyzing the data of the pretest and posttest by using t-test formula, the researcher found that $t$-test was 8.96. The researcher stated the criteria of testing hypothesis that if $t$-test is greater than $t$-table, the Alternative Hypothesis (Ha) was accepted and the Null Hypothesis (Ho) was rejected. It indicated that there was a significant different between the two tests. To know the significant difference of the tests, the researcher compared the value of t-test (8.96) with the t-table (1.68830) applying 0.05 level significance and 36 (37-1) degree of freedom (df). The researcher found that $\mathrm{t}_{\text {test }}$ was higher than $\mathrm{t}_{\text {table; }} \mathrm{t}_{\text {test }}$ was 8.96 while $\mathrm{t}_{\text {table was }} 1.68830$ (8.96 > 1.68830). The researcher has evidence to accept the Alternative Hypothesis (Ha) and reject the Null Hypothesis (Ho).

Based on the analysis of the research in the previous showed that when they played video game was effective to develop students' vocabulary mastery at class $\mathrm{H}$ fifth semester of Sorong Muhammadiyah University. It also can be seen from the distribution of pre test and post test scores were expressively different.

The data was a little equality with Lee et al. (2004) they founds that a math facts game for second graders deployed on handheld computers encouraged learners to complete a greater number of problems at an increased degree of difficulty. Learners playing the handheld game completed nearly three times the number of problems in 19 days as those using paper worksheets.

\section{CONCLUSION AND SUGGESTION}

Based on the research findings and discussion in the previous explanation, the conclusion can be stated that the playing video game can develop students' vocabulary mastery. The researcher concludes that, the result of pre-test and post-test in this research has been developed significant. Where pre-test is 6.51 and post-test is 8.5. It was proved through testing hypothesis in 37 degree of freedom (df) or $37-1=36$. It can be proved that there was a significant effect on the playing video game to develop students' vocabulary mastery. It showed that $\mathrm{t}$ test was 8.96 while $\mathrm{t}$ table was 1.68830 (8.96>1.68830), $\mathrm{t}_{\text {test }}$ was bigger than $\mathrm{t}_{\text {table. }}$. 
Based on the conclusion of the study the researcher would like to give several suggestions to other teacher and researcher, teacher should be consider to applying several video games in teaching and learning process, especially for games which has been proven effective in English language influence. To other researcher, the topic about this area was not new, there are some opportunity for other researchers to make different correlation about that. This study was only one of efforts in improving students' vocabulary. It is expected that the finding of this study will be used as a starting point of the future research on similar problems.

\section{References}

Arikunto, S. (1984). Dasar-Dasar Evaluasi Pendidikan Bina Aksara. Jakarta. (1996). Prosedur Penelitian Suatu Pendekatan Praktek. Jakarta: Rineka Cipta.

Denis, G. (2005). Motivation-driven educational game design: applying best practices to music education. Paper presented at the 2005 ACM SIGCHI International Conference on Advances in computer entertainment technology, Valencia, Spain.

Dickey, M. D. (2006). "Ninja Looting" for instructional design: The design challenges of creating a game-based learning environment. Paper presented at the $A C M$ SIGGRAPH 2006 conference, Boston.

Gee, J. P. (2005). Learning by design: Good video games as learning machines. Elearning and Digital Media, 2(1), 5-16.

Gros, B. (2007). Digital games in education: The design of games-based learning environments. Journal of research on technology in education, 40(1), 23-38.

Hornby A S. (1984). Oxford Advanced Learner's Dictionary, Fifth Edition (1331) (1995). Oxford Advance Learner's Dictionary of Current English. London: Oxford University Press.

Jenkins, H et al. (2003). Entering the education arcade. Computers in Entertainment, $1(1), 17$.

Johnson, W. L., Vilhjálmsson, H. H., \& Marsella, S. (2005, May). Serious games for language learning: How much game, how much AI?. In AIED (Vol. 125, pp. 306313).

Lee, J. et al. (2004). More than just fun and games: Assessing the value of educational video games in the classroom. Paper presented at the CHI '04 Extended Abstracts on Human Factors in Computing Systems, Vienna, Austria.

Napa, P. A. (1991). Vocabulary Development Skills. First Edition, Kanisius. Yoyakarta.

Nation Paul, (1994) New Ways of Teaching Vocabulary (USA: Teacher of English to Speaker of another Language/TESOL Inc)

Prensky Marc. (2006). Don't bother me mom--I'm learning. St. Paul, MN: Paragon House.

Sutomo. (1985). Tekhnik Penelitian dan Pendidikan. Bina Ilmu. Surabaya.

Syamsuddin AR et al. (2006). Metode Penelitian Pendidikan Bahasa. Bandung 
Waraich, A. (2004). Using narrative as a motivating device to teach binary arithmetic and logic gates. Paper presented at the 9th annual SIGCSE Conference on Innovation and Technology in Computer Science Education, Leeds, United Kingdom. 